УДК 378.147.091.313:001.895

DOI:

Віталій Бойчук, доктор педагогічних наук, дочент, заступник директора навчальнонаукового інституту педагогіки, психології, підготовки фахівців вищэӧ кваліфікації Вінницького державного педагогічного університету імені Михайла Коцююинського

Володимир Уманець, кандидат педагогічних наук, доцент, начальник інформаційно-обчислювального иентру

Вінницького державного педагогічного університету імені Михайла Коиюбинського

\title{
ЗАСТОСУВАННЯ ЕЛЕКТРОННИХ ОСВІТНІХ РЕСУРСІВ ЯК ІННОВАЦІЙНИЙ ЧИННИК УДОСКОНАЛЕННЯ ПІДГОТОВКИ МАЙБУТНІХ ПЕДАГОГІВ
}

У статті розглянуті підходи до здійснення інноваційного процесу навчання у ЗВО, особливе місие відводиться використанню інформаційно-комунікаційних технологій як інноваційного чинника удосконналення підготовки майбутнього вчителя. Автори вважають, щуо розроблення та впровадження інтелектуальних навчальних систем на основі ІКТ сприятиме підвищенню якості професійної освіти у ЗВО. Особливоі актуальності набуває проблема пошуку інноваційних методів, форм і засобів навчання на основі інформаційнокомунікаційних технологій (IКT), які сприятимуть генерації нового покоління педагогів.

Ключові слова: інноваційна освіта; інноваційне навчання; електронний освітній ресурс; інновації.

Jim. 8.

Vitaliy Boychuk, Doctor of Sciences (Pedagogy), Associate Professor, Deputy Director of Educational-Scientific Institute of Pedagogics, Psychology, Training of Specialists of Higher Qualification,

Vinnytsya Mykhaylo Kotsyubynskiy State Pedagogical University

Volodymyr Umanets, Ph.D.(Pedagogy), Associate Professor, Head of the Information and Computing Center of Vinnytsya Mykhaylo Kotsyubynskiy State Pedagogical University

\section{APPLICATION OF ELECTRONIC EDUCATIONAL RESOURCES AS AN INNOVATIONAL FACTOR FOR IMPROVEMENT OF FUTURE PEDAGOGUE PREPARATION}

The article considers the approaches to the implementation of the innovative learning process in the nstitution of higher education, a special place is devoted to the use of information and communication technologies as an innovative factor in reducing the preparation of the future teacher. The current stage of the development of higher education in Ukraine is characterized by a special intensity and scale of transformations, caused in particular by the European integration and globalization processes, which require reloading of the system of higher education in the direction of informatization and optimization of the educational process. In this context, the problem of finding the innovative methods, forms and means of learning based on information and communication technologies (ICTS), which will promote the generation of a new generation of teachers, will also provide an increase in the quality of training of future specialists in the field of education, in particular, teachers of vocational training.

The importance of the above problem is mentioned in a number of normative documents, including the Law of Ukraine "On Higher Education", the National Doctrine of the Development of Education in Ukraine in the XXI Century, the Law of Ukraine "On the National Program of Informatization", the State Program "Information and communication technologies in education and science". All these documents clearly define the priority of introducing the ICT high school in the educational process, as well as providing educational institutions with modern pedagogical software tools. One of the ways of solving the problem of finding innovative methods, forms and means of training is the development and introduction of electronic educational resources into the educational process of institutions of higher education.

Paying tribute to the existing developments in the theoretical and applied aspects of the problem, we note that the development and implementation of modern and effective EER for the training of a teacher of vocational training is not something new.

We believe that for the development and implementation of modern EER it is necessary to carry out the scientific analysis and refinement of the concept of electronic educational resources; analysis of EER structure; to study the features of EER design; theoretically substantiate and experimentally test the effectiveness of using the elearning resource to study the basics of computer-aided imaging of future educators in vocational education.

Keywords: an innovative education; an innovative teaching; electronic educational resources; innovations.

П остановка проблеми. Кінець XX початок XXI ст. характеризується революційними відкриттями в галузі високих технологій, зокрема в царині оброблення та передавання інформації, що стало наслідком науково-технічного прогресу на цьому етапі 


\section{ЗАСТОСУВАННЯ ЕЛЕКТРОННИХ ОСВІТНІХ РЕСУРСІВ ЯКІННОВАЦІЙНИЙ ЧИННИК УДОСКОНАЛЕННЯПІГОТОВКИ МАЙБУТНІХПЕДАГОГІВ}

розвитку суспільства, коли інформація стала однією $з$ найважливіших цінностей. Активне впровадження інформаційно-комунікаційних технологій не могло не торкнутися й системи освіти, котра є основою соціально-економічного й духовного розвитку суспільства, визначає положення держави в сучасному світі й людини в соціумі.

Розроблення інформаційних технологій і засобів навчання на їх основі розпочалося на теренах України ще у сімдесяті роки, але й сьогодні, незважаючи на всі зусилля як педагогів, так і науковців, IT використовуються недостатньо і неефективно розвиток інформаційнокомунікаційних технологій зумовив появу нової форми освіти - електронної (e-learning), тобто навчання з використанням IКТ.

Основою ж електронної освіти є електронні освітні ресурси (ЕОР), поняття ЕОР в Україні стало загальновживаним на початку XXI ст. Відповідно до наказу Міністерства освіти і науки, молоді та спорту України № 1060 від 01.10.2012 "Про затвердження Положення про ЕОР" закріпилося його базове визначення: “. ...навчальні, наукові, інформаційні, довідкові матеріали та засоби, розроблені в електронній формі та представлені на носіях будь-якого типу або розміщені у комп'ютерних мережах, які відтворюються за допомогою електронних цифрових технічних засобів і необхідні для ефективної організації освітнього процесу, в частині, що стосується його наповнення якісними навчально-методичними матеріалами...".

Тому саме система освіти детермінує становлення світогляду інформаційного суспільства через формування та підвищення інформаційної культури людей. Водночас, забезпечення галузі освіти теорією та практикою розроблення та використання IКТ є одним із найважливіших напрямів процесу модернізації освіти, зокрема вищої. Актуальність використання IКТ у навчальному процесі потребує підготовки майбутніх учителів до їх застосування.

Інформаційні технології визначають як “сукупність процесів збирання, передавання, перероблення, зберігання та доведення до користувачів інформації, що реалізується на базі персональних комп'ютерів, комп'ютерних мереж і засобів зв'язку, для яких характерна наявність “дружнього” середовища роботи користувача" (В. Глушков, Ю. Данилевський, Н. Макарова та ін.). У нашому дослідженні під ІКТ розуміємо технології, що функціонують на базі електроннообчислювальної техніки і систем зв'язку, котрі дають можливість забезпечити різні категорії користувачів послугами електронної техніки щодо збирання, передавання, зберігання й оброблення інформації в усіх царинах суспільного життя.

Розвиток сучасної інформаційної техніки спричинив виникнення якісно нових умов функціонування системи освіти. Це зумовлює необхідність вивчення особливостей впливу процесу інформатизації на модернізацію формальних і змістових аспектів навчального процесу. Щоб випускник вищої школи знайшов своє місце в інформаційному суспільстві, він має опанувати IКТ, оволодіти навичками використання комп'ютера як інструменту повсякденної діяльності. Водночас, на думку О. Пєхоти, ці технології мають полегшити опанування студентами новими знаннями, набуття ними умінь і навичок. Сучасна комп'ютерна техніка та засоби телекомунікацій надають можливість оперативно здобувати, поширювати й обробляти необхідну інформацію з навчальною метою. Тому, наголошує науковець, вчитель зобов'язаний вміти користуватися цими засобами. Відзначимо, що саме внаслідок інформатизації освіти і впровадження IКТ у навчальний процес стало можливим забезпечення якісно нового рівня підготовки фахівців різних напрямів, а, отже, якісно нового підходу до формування професійної компетентності майбутніх учителів.

Виявленню особливостей педагогічної науки в умовах використання ІКТ присвячено низку досліджень (О. Алексєєв, А. Андрєєв, В. Биков, Я. Ваграменко, Р. Гуревич, М. Жалдак, М. Кадемія, Б. Канаєв, А. Ковалів, Г. Козлакова, А. Коломієць, А. Кравцова, М. Лапчик, А. Литвин, В. Лукін, В. Майєр, Д. Матрос, Н. Морзе, І. Роберт, С. Сисоєва, І. Соколова, Н. Стадник, Б. Старіченко та ін.). У роботах цих науковців розглядаються проблеми вдосконалення освіти у зв'язку із застосуванням засобів ІКТ, досліджуються педагогічні умови зміни парадигми самого навчального процесу в напрямі як його демократизації і відкритості, так і модифікації форм навчальної взаємодії між учасниками освітнього процесу, а також розвитку та модернізації дидактичних принципів навчання на основі ІКТ.

Р. Гуревич і М. Кадемія стверджують, що розвиток ІКТ, особливо Інтернет-технологій та їх використання в усіх галузях економіки дало стрімкий імпульс розвитку освіти. Нині немає навчального закладу, в якому не застосовуються комп'ютери, інформаційно-комунікаційні технології та Інтернет. Педагоги все частіше використовують нові технічні досягнення в освітній діяльності [1, 6]. Проте, вивчення вітчизняного та зарубіжного 


\section{ЗАСТОСУВАННЯ ЕЛЕКТРОННИХ ОСВІТНІХ РЕСУРСІВ \\ ЯК ІННОВАЦЙНИЙ ЧИННИК УДОСКОНАЛЕННЯПІДГОТОВКИ МАЙБУТНІХПЕДАГОПІВ}

досвіду інформатизації вказує на те, що відсутність комплексного впровадження засобів IКТ у цілях освіти спричинила розповсюдження практики використання комп’ютера для “латання дірок” традиційної методики навчання. Таке застосування засобів ІКТ дискредитує саму ідею інформатизації освіти (І. Роберт) [2].

Зазначимо, що IКТ умовно діляться на два класи: універсальні та професійно орієнтовані. До універсальних відносять текстові редактори, системи управління базами даних, електронні таблиці, засоби моделювання об'єктів, процесів і систем, 3 допомогою яких можна розв'язувати завдання в різноманітних галузях. До професійно орієнтованих належать технології, максимально адаптовані до конкретної професії та призначені для розв’язання конкретних професійних завдань: системи бухгалтерського обліку, бібліотечні системи, перекладацькі системи, навчальні системи та ін.

Нині є два явно виражених підходи до ролі інформаційно-комунікаційних технологій у навчанні. У першому пропонується розглядати їх як дидактичний процес, організований iз використанням сукупності впроваджуваних у системи навчання принципово нових засобів і методів оброблення даних (методів навчання), що передбачає цілеспрямоване створення, передавання, зберігання й відображення інформаційних продуктів (даних, знань, ідей) із найменшими витратами i відповідно до закономірностей пізнавальної діяльності здобувачів вищої освіти. У другому випадку йдеться про створення певного технічного середовища навчання, в якому ключове місце посідають використовувані ІКТ. Отже, в одному випадку говоримо про інформаційно-комунікаційні технології навчання як процес навчання, а в іншому випадку - про застосування IКТ у навчанні як інноваційного чинника.

Ми дотримуємося останнього підходу, тобто використання в навчанні вчителів інформаційнокомунікаційних засобів як інноваційного чинника. У зв'язку з цим термін “інформаційні технології навчання" визначаємо як засоби і методи підготовки, передавання та представлення інформації здобувачам вищої освіти, які використовують комп'ютер як засіб підтримки навчального процесу, що кардинально змінює систему форм i методів навчання, котра динамічно розвивається. У зв'язку з цим, передусім, потребує вдосконалення процес використання персонального комп'ютера як інструменту реалізації тієї чи іншої педагогічної технології. Цей напрям необхідно підсилити за рахунок активного застосування сучасних технічних засобів: мультимедійних проекторів, електронних навчальних дошок, автономних навчальних комплексів. Важливою передумовою реалізації та впровадження ІКТ у навчальний процес $\epsilon$ наявність обладнаних аудиторій із мультимедійним проектором, персональним комп'ютером для викладача, екраном або інтерактивною дошкою, а також наявність доступного інформаційного освітнього середовища, в якому проходить навчальний процес (комп'ютерних класів, електронних бібліотек, медіатек, доступ до Інтернет тощо). Проте нині ця проблема в Україні має не лише педагогічний, а й матеріально-технічний і фінансовий характер.

Вартим уваги, на наш погляд, $є$ твердження про те, що ІКТ даватиме гарні результати, коли 3'явиться нове покоління педагогів, готових застосовувати цей засіб, а також методистів, які розроблятимуть методи використання IКТ $[3,19]$. Інформаційно-технологічна компетентність вчителя є однієї з важливих складових його підготовки в сучасному інформаційному суспільстві. Розглянута характеристика передбачає:

- володіння педагогом навичками роботи 3 IKT;

- здатність знаходити та представляти потрібну інформацію;

- потребу в більш глибокому вивченні питань технік, технологій, методик;

- розв'язання професійних завдань різного характеру.

Ефективне формування інформаційнотехнологічної компетентності може бути здійснене за допомогою різних методичних матеріалів: творчі завдання, віртуальний лабораторний комплекс, комп'ютерне моделювання, комп'ютерні навчальні програми [2; 3; 4], навчальні посібники та навчальні методичні комплекси, методичні рекомендації для написання курсових і кваліфікаційних робіт.

Нині виокремлюються щонайменше три взаємопов'язані напрями застосування IКТ в освіті: забезпечення аудиторних занять, електронні бібліотеки, Інтернет. У розумінні та застосуванні терміну “комплексне використання IКТ” виокремлюють три площин: на рівні навчального закладу, на рівні навчальної дисципліни, на рівні одного року навчання окремій дисципліні [4].

Водночас науковці стверджують, що використання IКТ у навчальному процесі буде комплексним, якщо воно передбачає: по-перше, 


\section{ЗАСТОСУВАННЯ ЕЛЕКТРОННИХ ОСВІТНІХ РЕСУРСІВ ЯКІННОВАЦЙНИЙ ЧИННИКУДОСКОНАЛЕННЯПДГОТОВКИ МАЙБУТНІХПЕДАГОГІВ}

використання IКТ в єдиній, органічно пов'язаній, дидактично доцільній системі, коли різні засоби доповнюють і збагачують один одного; по-друге, використання IКТ у різних видах навчальної діяльності. Грунтуючись на такому розумінні комплексного використання ІКТ, розглядатимемо процес формування професійної компетентності майбутніх учителів технологій.

Завдяки мультимедійності ІКТ дають змогу осмислено й гармонійно поєднувати різні види інформації, презентувати її в різних формах, таких як: зображення, включаючи фотографії, креслення, карти і слайди; записи мовлення, звукові ефекти й музика; відео, складні відеоефекти й анімаційне імітування; анімації та симуляції. Презентації, що супроводжуються яскравими зображеннями й анімацією, візуально привабливіші, ніж статичний текст, і здатні збільшувати рівень пізнавальної активності студентів. У поєднанні з гіпертекстом мультимедіа утворюють системи гіпермедіа (hypermedia - надсередовище), що містять не лише текстову, а й графічну чи візуальну інформацію. 3'являється можливість поєднати текстову й графічну інформацію зі звуком, анімаційними роликами і відеофрагментами [5, 62].

Окрім того, віртуальна присутність користувача в програмному навчальному середовищі мобілізує всі основні канали сприйняття нової навчальної інформації - візуальний, слуховий і моторний, що починають працювати паралельно й узгоджено таким чином, як це зазвичай відбувається в повсякденній реальності. Сприйнята таким чином навчальна інформація, що спирається не на розсіяну, а на виробничу увагу, ефективніше піддається опрацюванню у результаті розумових операцій, надійніше зберігається в пам'яті й швидше згадується. Адже саме вибіркова увага, на думку фахівців із когнітивної психології, є основою цілеспрямованого й ефективного навчання.

Важливою властивістю ІКТ є інтерактивність (або відкритість до спілкування), що дає користувачам можливість зворотного зв'язку. Інтерактивними називають засоби, що забезпечують безперервну діалогову взаємодію комп'ютера 3 користувачем. Ефективним $\epsilon$ інтерактивний діалог (діалоговий режим) - пряма взаємодія між людиною і комп'ютером, комп'ютерами в мережі або між комп'ютером і периферійним пристроєм, за якого зв'язок між взаємодіючими системами не переривається. Часто його називають інтерактивним режимом, або режимом “on-line" $[6,111]$ - взаємодія користувача 3 програмною (програмноапаратною) системою, яка характеризується (на відміну від діалогового, такого, що передбачає обмін текстовими командами, запитами і відповідями, запрошеннями) реалізацією розвиненіших засобів ведення діалогу (наприклад, можливість ставити питання в довільній формі, 3 використанням “ключового” слова, у формі 3 обмеженим набором символів та ін.); у процесі цього забезпечується можливість вибору варіантів змісту навчального матеріалу, режиму роботи з ним. Інтерактивний режим взаємодії користувача 3 комп'ютером характерний тим, що кожний його запит викликає у відповідь дію програми i, навпаки, робота останньої вимагає реакції користувача $[7,454]$.

Помітним аспектом інформатизації вищої освіти є реалізації особистісно орієнтованого навчання з використанням IКТ. Нині визначені й розкриті дидактичні принципи особистісно орієнтованого навчання в умовах використання IКТ: урахування самоцінності індивідуума; підхід до здобувача вищої освіти як до активного суб'єкта пізнання; опора на суб'єктивний досвід студента; орієнтація на саморозвиток, самонавчання, самоосвіту студента; урахування індивідуальних психофізіологічних особливостей студента; розвиток комунікативних здібностей особистості.

При цьому ми вважаємо за потрібне показати:

- використання IКТ в освітньому процесі педагогічного ЗВО;

- ЕОР як складову інформаційного навчального середовища, орієнтованого на формування професійної компетентності майбутніх учителів;

- мультимедійні педагогічні програмні засоби та комп'ютерна графіка в підготовці вчителя технологій;

- підвищення ефективності системи формування художньо-графічної компетентності майбутніх учителів технологій засобами IКТ.

Розглянемо детальніше інноваційні навчальні системи у підготовці вчителя технологій за трьома основними напрямами.

Засоби пошуку та обміну інформації.

Інформаційний пошук нині ефективно забезпечують мережеві технології, що бурхливо розвиваються, в тому числі в освіті. Освітня складова Інтернет охоплює електронну пошту (e-mail); телеконференції (Usenet); відеоконференції; можливість публікації власної інформації, створення власної домашньої сторінки і розміщення іï на Веб-сервері; доступ до сучасних інформаційних ресурсів (електронні словники, довідники, енциклопедіi) через довідкові каталоги і пошукові системи; чати (Chat), навчальні блоги, Вікі-технології тощо.

Використання комп'ютерних мереж має низку 
беззаперечних переваг перед вже наявними технологіями навчання. Найважливішими з них є:

1. Розширення інформаційних ресурсів суб'єктів комп'ютерної мережі. Під'єднання до глобальної комп'ютерної мережі дає можливість користувачам одержати безоплатний доступ до величезних масивів інформації, в тому числі навчального призначення, сучасних комп'ютерних програм, каталогів найкращих світових бібліотек, різноманітних баз даних тощо.

2. Можливість значного підвищення кваліфікації вчителя або викладача як керівної особи навчально-виховного процесу. Комп'ютерні мережі дають можливість не лише застосовувати у викладацькій діяльності широкий спектр навчальних матеріалів, а й використовувати для свого професійного зростання мережеві інформаційні ресурси, підтримувати тісні зв'язки iз своїми колегами, підвищувати свою кваліфікацію шляхом дистанційного навчання за різними програмами.

3. Додаткові навчальні можливості для здобувачів вищої освіти. Доступ до Інтернету дає змогу підвищення комп'ютерної грамотності студентів, відпрацювання методик чи способів, за допомогою яких можна було б найбільш повно використовувати можливості глобальних мереж. Крім того, користувач одержує унікальну можливість використовувати різноманітні онлайнові педагогічні програмні засоби, включитися в заочні курси, що проводяться національними та зарубіжними навчальними закладами, одержати мовну практику в спілкуванні на он-лайнових конференціях, та врешті, включитись у діалог 3 учнями, студентами та викладачами всього світу $[8,7]$.

Інтернет-ресурси становлять найпотужніший нині засіб одержання навчальної інформації, представленої в електронному вигляді, та розв'язання різноманітних навчальних завдань. Доступ до Інтернет означає доступ до величезного сховища інформації, якість якої визначає нові властивості освіти і знань загалом.

Телекомунікаційні технології відкрили кардинально нові можливості для діяльності студентів і викладачів. Спостереження показують, що робота в комп'ютерних мережах активізує потребу здобувачів вищої освіти бути членами соціальної спільноти. Фахівці наголошують на поліпшенні взаємодії студентів через телекомунікаційне спілкування, підвищення їхнього інтересу до навчання і, як наслідок, загальне зростання успішності. Технології Інтернет відкривають перед викладачами та здобувачами вищої освіти широкі можливості доступу до нетрадиційних джерел інформації в будь-якому куточку світу, засобів надання й маніпулювання цією інформацією, використовуючи аудіо-, відеоінформацію й гіпертекст. Водночас, для того, щоб знайти необхідний матеріал в Інтернет, необхідно осмислити поняття i визначити предметну галузь, без чого неможливо грамотно скласти запит на пошук інформації.

3 метою візуалізації навчального матеріалу, забезпечення інтерактивності освітнього процесу, підвищення інтересу студентів до навчання, поглиблення їх знань та реалізації освітніх завдань, ми пропонуємо такі сервіси:

1. WordArt - веб-сервіс, який дозволяє створити хмару слів 3 тексту, введеного користувачем або з веб-сторінки 3 адресою, наприклад, за допомогою хмар тегів можна реалізовати глосарій основних термінів до кожної 3 тем навчальної дисципліни.

2. Mind Meister - сервіс для створення ментальних карт (карт знань).

Ментальні карти - це один із способів опрацювання інформації графічно та візуально, вид запису ідей, думок. Вважаємо, що за допомогою ментальних карт досить вдало вирішуються питання створення опорних конспектів, ключових понять до кожної з тем.

Варто відзначити позитивні аспекти використання в освітньому процесі відеохостингу Youtube, що дозволяє розміщувати навчальні відеоматеріали 3 можливістю створення викладачем власного Youtube-каналу. В структурі дидактичних матеріалів ЕОР, важливе місце займає комплекс спеціально підібраних відеоуроків основ роботи в середовищі для комп'ютерної верстки.

Важливим етапом освітнього процесу $є$ контроль знань. На наш погляд, для організації перевірки засвоєння студентами здобутих знань доцільно використовувати сервіси для створення тестів. Викладачам, які є користувачами Googleакаунта в цій ситуації зручно використовувати сервіс Google Forms, який дозволяє створювати тестові форми-опитувальники, що можуть містити питання різних типів (з вибором однієї правильної відповіді, з множинним вибором правильних відповідей, питаннями на зіставлення, питання 3 введенням короткої відповіді, на встановлення логічної або хронологічної послідовності тощо ).

Серед локальних програмних продуктів для створення контрольних тестів часто використовують сервіс My Test X. Враховуючи наш практичний досвід, хочемо зауважити, що у EOP, для створення контрольних тестів, окрім описаних сервісів також доцільно використовувати 
можливості програми MS PowerPoint зі спеціально-прописаним макросом “Тестування”. За допомогою цієї програми можемо створити тематичне бліц-тестування до кожної лекції чи практичного заняття. Перевагою такого тестування є його проведення без встановлення спеціального програмного забезпечення та підключення до мережі Інтернет.

Також для перевірки отриманих знань, можемо використовувати дидактичні матеріали, створені за допомогою сервісу Learning Apps, який є сервісом Web 2.0 для підтримки освітніх процесів у навчальних закладах різних типів. Це конструктор для розробки інтерактивних завдань за різними предметними дисциплінами для застосування на уроках і в позакласній роботі. Сервіс містить галерею загальнодоступних інтерактивних завдань, яка щодня поповнюється новими матеріалами, які створені викладачами різних країн.

Висновки. Використання описаних вище інструментальних програмно-технічних та апаратних засобів дозволить максимально структурувати та унаочнити навчальні матеріали та зробити освітній процес інтерактивним. Ми вважаємо, що такий спосіб подання навчального матеріалу дозволяє здобувачам вищої освіти “не потонути в потоці теоретичного матеріалу”, і легко знайти відповіді на питання, що виникають в процесі навчання. Можемо стверджувати, що на нинішньому етапі розвитку освіти оволодіння інформаційними компетентностями в поєднанні 3 інформаційно-комунікаційними технологіями $є$ ефективним методом розвитку професійних здібностей майбутніх учителів і залучення їх до надбань національної та світової культури. Використання педагогічних можливостей IКТ у процесі підготовки майбутніх учителів дозволить забезпечити формування не лише інформаційнотехнологічної компетентності, а й загалом професійної компетентності майбутніх учителів на якісно новому рівні, що відповідає запитам особистості, суспільства і держави.

\section{ЛІТЕРАТУРА}

1. Гуревич Р. С., Кадемія М. Ю. Інформаційнотелекомунікаційні технології в навчальному процесі та наукових дослідженнях: Навчальний посібник для студентів педагогічних ВНЗ і слухачів інститутів післядипломної педагогічної освіти. Вінниця, 2005. 365 с.

2. Роберт И. В., Самойленко П. И.. Москва, 1998.176 с.

3. Гуржій А. М., Биков В. Ю. Теоретико-методологічні засади використання інформаційно-комунікаційних технологій у навчальному процесі. Збірник матеріалів науково-методичного семінару “Інформатизація освіти: стан, проблеми, перспективи”. 2011. С. 47-59.
4. Уманець В.О., Кадемія М.Ю., Кізім С.С. Інформаційно-комунікаційні технології навчання : Ч.1 навч. посібник. Вінниця, 2017. 410 с.

5. Бойчук В.М., Кадемія М.Ю. Сучасні електронні технології в неперервній освіті. Професійна підготовка педагогічних кадрів у контексті європейського освітнього простору: матеріали міжвуз. наук.-прак. конф. аспірантів та молодих вчених. Хмельницька гуманітарно-педагогічна академія. Хмельницький, 2008. С. $163-170$.

6. Безуглий А.І. Віртуальний університет: проблеми створення і функціонування. Сучасні інформаційні технології та інноваційні методики навчання в підготовці фахівців : методологія, теорія, досвід, проблеми : зб. наук. праць, №46 / ТОВ Планер - Київ, Вінниця. 2016. C. $110-114$

7. Великий тлумачний словник сучасної української мови : 250000 / уклад. та голов. ред. В. Т. Бусел. Київ, Ірпінь. 2001.2005 c.

8. Gurevych R.S. Blended learning and innovative tehnologies in training of future specialists in foreign higher education insitutions. Порівняльна професійна педагогіка № 1 (Т. 7), Хмельницький, 2017. С. 7-12.

\section{REFERENCES}

1. Hurevych, R. S. \& Kademiia, M. Yu. (2005). Informatsiino-telekomunikatsiini tekhnolohii $\mathrm{v}$ navchalnomu protsesi ta naukovykh doslidzhenniakh [Information and telecommunication technologies in the educational process and scientific researches]. A manual for students of pedagogical universities and students of institutes of postgraduate pedagogical education. Vinnytsia, 365 p. [in Ukrainian].

2. Robert, I. V. \& Samoylenko, P. I. (1998). Informatsionnye tekhnologii $v$ nauke $i$ obrazovanii [Information technology in science and education]. Moscov, 176 p. [in Russian].

3. Hurzhii, A. M. \& Bykov, V. Yu. (2011).Teoretykometodolohichni zasady vykorystannia informatsiinokomunikatsiinykh tekhnolohii u navchalnomu protsesi [Theoretical and methodological principles of usage the information and communication technologies in the educational process]. Zbirnyk materialiv naukovometodychnoho seminaru "Informatyzatsiia osvity: stan, problemy, perspektyvy"-ACollection of Materials of the Scientific and Methodical seminar "Informatization of education: state, problems, perspectives". (pp.47-59). [in Ukrainian].

4. Umanets, V.O., Kademiia, M.Iu. \& Kizim, S.S. (2017). Informatsiino-komunikatsiini tekhnolohii navchannia: ch.1 navch. Posibnyk [Information and communication technologies of teaching: Part 1 of teaching. Manual]. Vinnytsia, 410 p. [in Ukrainian].

5. Boichuk, V.M. \& Kademiia, M.Iu. (2008). Suchasni elektronni tekhnolohii v neperervnii osviti [Modern electronic technologies in continuous education]. Profesiina pidhotovka pedahohichnykh kadriv u konteksti yevropeiskoho osvitnoho prostoru: materialy mizhvuz. nauk.-prak. konf. aspirantiv ta molodykh $v c h e n y k h$ - Professional training of pedagogical staff in the context of the European educational space: the 


\section{THEORETICALBASIS FORTHE DEVELOPMENTOF FOREIGNGRAMMATICALCOMPETENCE IN THE PROCESS OF STUDENTS OF PHILOLOGICAL SPECIALITIES TRAINING}

materials of inter-university. sciences. conf. graduate students and young scientists. Khmelnytskiy Humanitarian Pedagogical Academy. Khmelnytskyi, pp. 163-170. [in Ukrainian].

6. Bezuhlyi, A.I. (2016). Virtualnyi universytet: problemy stvorennia i funktsionuvannia [Virtual University: Problems of Creation and Functioning]. Modern information technologies and innovative methods of training in the training of specialists: methodology, theory, experience, problems: a collection of scientific works. No. 46. Kyiv, Vinnitsa. pp. 110-114. [in Ukrainian].

7. Busel, V. T. (Ed.). (2001).Velykyi tlumachnyi slovnyk suchasnoi ukrainskoi movy : 250000 [Great explanatory dictionary of the modern Ukrainian language: 250,000$]$. Kyiv, Irpin. 2005 p. [in Ukrainian].

8. Gurevych, R.S. (2017). Blended learning and innovative tehnologies in training of future specialists in foreign higher education insitutions. Comparative professional pedagogy. No. 1 (Vol. 7), Khmelnytskyi, pp. 7-12. [in English].

Стаття надійшла до редакції 16.04.2019

UDC 372.881.111.1

DOI:

Olha Mahdyuk, Ph.D.(Pedagogy), Associate Professor of the Foreign Language Practice and Methodology of Teaching Department, Khmelnytskiy National University

\section{THEORETICAL BASIS FOR THE DEVELOPMENT OF FOREIGN GRAMMATICAL COMPETENCE IN THE PROCESS OF TRAINING OF STUDENTS OF PHILOLOGICAL SPECIALITIES}

The article attempts to prove that grammatical competence provides systematic knowledge of the lexical, morphological, syntactic, phonetic and spelling aspects of language for the construction of meaningful and coherent utterances; possession of grammatical notions, as well as means of expressing grammatical categories; skills and abilities to adequately use the grammatical phenomena in speech activity in various communication situations for solving speech-mental problem tasks. The emphasis has been placed on the importance of raising teachers' awareness about the diversity of methods and approaches of foreign language training of student of philological specialities. The main approaches of the consciously-communicative method have been suggested as an important component of grammatical competence development. It was established that the specific features of vocational language education in higher education include the presence of certain time constraints; group work, not individual work; age of students; the inability to directly immerse all students in the language environment in the study of foreign languages. This implies the need to develop new teaching methods, in particular, methods for the formation of foreign grammatical competence with the use of elements of conventional and alternative teaching methods.

Keywords: grammatical competence; students of philological specialities; foreign language studying; methods; approaches.

Ref. 8.

Ольга Магдюк, кандидат педагогічних наук, доиент кафедри практики іноземної мови та методики викладання Хмельнищького національного університету

\section{ТЕОРЕТИЧНІ ЗАСАДИ РОЗВИТКУ ІНШОМОВНОЇ ГРАМАТИЧНОЇ КОМПЕТЕНТОСТІ У ПРОЦЕСІ ПІДГОТОВКИ СТУДЕНТІВ ФІЛОЛОГІЧНИХ СПЕЦАЛЬНОСТЕЙ}

У статті зроблено спробу обтрунтувати думку, що граматична компетентність забезпечує систематичне знання студентами лексичних, морфологічних, синтаксичних, фонетичних і правописних аспектів мови для побудови значущих і послідовних висловлювань; володіння граматичними поняттями, $a$ також засобами вираження граматичних категорій; уміння та навички адекватно використовувати граматичні явища в мовленнєвій діяльності в різних комунікаційних ситуаціях для вирімення мовленнєвопсихічних задач. Наголочено на важливості підвищення обізнаності вчителів щодо різноманітності методів i підходів у процесі підготовки студентів філологічних спеціальностей з іноземної мови. Основні підходи свідомо-комунікативного методу були запропоновані як важливий компонент розвитку граматичної компетентності. Встановлено, щзо особливості професійної мовної освіти у вищій освіті включають наявність певних часових обмежень; групова робота, а не індивідуальна робота; вік студентів; неможливість безпосередньо занурити всіх студентів у мовне середовище у прочесі вивчення іноземної мови. Це передбачає 